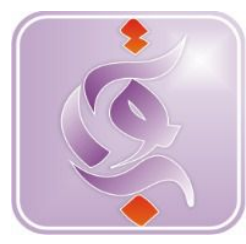

\title{
PENGARUH KINERJA TERHADAP PROFESIONALITAS DOSEN DI UIN IMAM BONJOL PADANG
}

\author{
Received: 24 $4^{\text {th }}$ September 2018; Revised: $12^{\text {th }}$ October 2018; Accepted: $25^{\text {th }}$ November 2018
}

\section{Winbaktianur}

UIN Imam Bonjol Padang

Email: winbaktianur@uinib.ac.id

Nur 'Aisyiah Yusri

UIN Imam Bonjol Padang

Email:nuraisyiah@uinib.ac.id

\begin{abstract}
ABSTRAK. Dosen mengemban tugas untuk melaksanakan tridharma perguruan tinggi, pengajaran, penelitian dan pengabdian masyarakat. Dalam melaksanakan tugasnya dosen diminta untuk melaksanakan pengajaran di kelas, melaksanakan penelitian dan pengabdian masyarakat. Untuk itu pemerintah memberikan berbagai upaya untuk memberikan penghargaan kepada dosen, selain gaji dan tunjungan dosen, juga menerima tunjangan berupa sertifikasi. Aturan-aturan diterapkan bagi dosen, di antaranya mengenai jam kerja. Tujuan penelitian ini adalah untuk melihat pengaruh kinerja terhadap profesionalitas dosen dengan adanya penerapan jam kerja dosen. Hasil penelitian menunjukkan kinerja mempengaruhi profesionalitas dosen karena adanya penerapan jam kerja.
\end{abstract}

Kata Kunci : Kinerja, profesionalitas, jam kerja

\section{A. PENDAHULUAN}

Penilaian kinerja dapat juga disebut sebagai prestasi kerja, dimana prestasi kerja adalah suatu kombinasi hasil gabungan antara keahlian dan motivasi, dimana keahlian adalah usaha ciri yang stabil. Prestasi kerja juga sangat bermanfaat dalam bekerja dimana seseorang dapat bekerja dengan baik dalam sebuah perusahaan yang ditempatinya. Individu dalam bekerja akan selalu dilihat hasil kerja atau prestasi kerjanya. Biasanya dikenal dengan istilah kinerja. Kinerja atau performance berasal dari kata to perform yang berarti memenuhi satu obligasi dan memenuhi yang dijanjikan atau diharapkan (Swanson, 1999). Setiap individu yang bekerja dalam sebuah organisasi dituntut memenuhi keseluruhan tugas yang diberikan untuk menghasilkan kinerja (performance) dan produktivitas tinggi serta keunggulan kompetitif organisasi.

Kinerja (performance) adalah hasil pekerjaan yang dicapai seseorang berdasarkan persyaratan-persyaratan pekerjaan (job requirement). Suatu pekerjaan mempunyai persyaratan tertentu untuk dapat dilakukan dalam mencapai tujuan yang disebut juga sebagai standar pekerjaan (job standard) (Bangun, 2012).

Sebagai bagian dari organisasi di perguruan tinggi, dosen dituntut untuk mempunyai kinerja. Sebagai pekerja organisasi (Manuel dan Asuquo, 2010), dosen dituntut untuk memenuhi tugasnya dan menunjukkan kinerja yang positif. Sebagaimana disitir UNESCO dan Volunteer Services Overseas atau VSO (dalam Amstrong, 2009), hal ini dikarenakan dosen merupakan pemain sentral di organisasi perguruan tinggi dan pihak yang paling bertanggung jawab dalam menciptakan suasana kampus yang ilmiah. Dosen merupakan salah satu komponen esensial dalam suatu sistem pendidikan di perguruan tinggi. Bahkan lebih jauh lagi peran, tugas, dan tanggung jawab dosen sangat penting dalam 
mewujudkan tujuan pendidikan nasional, yaitu mencerdaskan kehidupan bangsa, meningkatkan kualitas manusia Indonesia, yang meliputi kualitas iman/takwa, akhlak mulia, dan penguasaan ilmu pengetahuan, teknologi, dan seni, serta mewujudkan masyarakat Indonesia yang maju, adil, makmur, dan beradab (Dikjen Dikti, 2010), (Dalam Shaleh, 2013).

Merujuk Undang-Undang Nomor 20 Tahun 2003 tentang Sistem Pendidikan Nasional Bab XI Pasal 39 ayat 2 menyebutkan "Pendidik merupakan tenaga profesional yang bertugas merencanakan dan melaksanakan proses pembelajaran, menilai hasil pembelajaran, melakukan pembimbingan dan pelatihan, serta melakukan penelitian dan pengabdian kepada masyarakat, terutama bagi pendidik pada perguruan tinggi”.

Berdasarkan Petunjuk Teknis Pelaksanaan Angka Kredit Jabatan Dosen Peraturan Menteri Pendayagunaan Aparatur Negara Nomor 36/D/0/2001, bidang kegiatan dosen dalam melaksanakan pendidikan dan pengajaran meliputi: (1) memberi kuliah/tutorial dan menguji (2) menyelenggarakan kegiatan praktek (3) membimbing seminar mahasiswa (4) membimbing praktek kerja nyata (5) membimbing pembuatan skripsi/karya tulis (6) bertugas dalam panitia ujian akhir (7) membina kegiatan kemahasiswaan dan (8) melaksanakan pengembangan program studi/modul. Sementara tugas penelitian mencakup merancang dan melaksanakan penelitian serta mempublikasikannya dalam bentuk jurnal dan buku. Adapun bidang pengabdian masyarakat terkait dengan keterlibatan dan peran serta dalam pengembangan masyarakat dan kepanitiaan. Keseluruhan tugas dimaksud dinyatakan dalam beban kerja dosen setara dengan 40,5 jam per minggu. Namun kenyataannya seringkali pekerjaan harus dilakukan dosen di luar jam kerja. Ini berarti, pekerjaan seorang dosen merupakan pekerjaan yang kompleks. (Seniati, 2006).
Di samping itu, ada beberapa masalah lain terkait dengan pelaksanaan tugas dan pemenuhan kinerja dosen ini. Manuel dan Asuquo (2010) dalam kasus Nigeria menemukan sikap yang unfavourable dan persepsi yang negatif terhadap pekerjaan dikarenakan persoalan remunerasi dan jaminan pensiun yang dipandang tidak memadai. Persepsi dan penelitian mengenai kualitas dan profesonalisme dosen, terutama dalam hal layanan, juga masih rendah.

Dosen mengemban tugas untuk melaksanakan tridharma perguruan tinggi, pengajaran, penelitian dan pengabdian masyarakat. Dalam melaksanakan tugasnya dosen diminta untuk melaksanakan pengajaran di kelas, melaksanakan penelitian dan pengabdian masyarakat baik di lingkungan kampus maupun di luar kampus. Untuk itu pemerintah memberikan berbagai upaya untuk memberikan penghargaan kepada dosen, selain gaji dan tunjungan dosen, juga menerima tunjangan berupa sertifikasi.

Sertifikasi dosen telah mulai diberikan sejak tahun anggaran 2010 bagi dosen yang berpangkat lektor dan lektor kepala dan dinyatakan lulus sertifikasi. Kemudian Kepangkatan untuk memperoleh tunjangan sertifikasi dosen dimulai dengan jenjang asisten ahli.

Menurut Shaleh (2013) mengutip pendapat beberapa ahli bahwa secara teoretik terdapat dua faktor yang mempengaruhi kinerja individu dalam organisasi, yaitu faktor personal (Motowidlo, dkk., 1997; Schmitt, dkk., 2003) dan situasi/lingkungan (Tett dan Burnet, 2003). Faktor personal mencakup kemampuan mental umum, kepribadian, kapabilitas individual, dan keterampilan. Faktor situasi meliputi dukungan dan situasi lingkungan dan organisasi yang dipersepsi oleh individu yang dipandang sebagai fasilitator bagi pencapaian kinerja yang efektif (Sonnentag dan Frese, 2002).

UIN Imam Bonjol sebagai salah satu institusi Perguruan Tinggi Keagamaan Islam Negeri juga menerapkan hal yang 
sama. Dosen-dosen yang layak dan lulus serta mempunyai sertifikat pendidik diberikan tunjangan sertifikasi berdasarkan pangkat dan golongannya. Sebagai dosen yang berstatus Aparatus Sipil Negara (ANS), dosen juga terikat dengan aturanaturan yang ditetapkan oleh Kementerian Agama serta UIN Imam Bonjol Padang. Salah satunya adalah Peraturan Menteri Agama Republik Indonesia Nomor 5 Tahun 2017 tentang jam Kerja Dosen Pada Perguruan Tinggi Kegamaan Islam. Menindaklanjuti Peraturan Menteri Agama ini, UIN Imam Bonjol melalui Rektor mengeluarkan edaran Nomor : B.592/In.02/B.IV/Kp.04.1/03/2017

Tentang Jam Kerja Dosen Di Lingkungan UIN Imam Bonjol Padang, pada tanggal 9 Maret 2017.

Salah satu pendekatan untuk memahami kinerja dalam kajian psikologi positif ialah perilaku organisasi positif (POB) yang menekankan pada peningkatan kinerja. Ini merujuk pada apa yang mempengaruhi kinerja ialah perilakuperilaku kerja dan organisasi yang dimunculkan secara positif, terutama berkaitan dengan kualitas psikologis individu dan dampaknya terhadap peningkatan kinerja (Bakker \& Schaufeli, 2008; Cameron, 2005). Di samping itu, POB merujuk pada penelitian dan penerapan yang berorientasi positif kekuatan sumber daya manusia dan kapasitas psikologis yang dapat diukur, dikembangkan, dan efektif untuk peningkatan kinerja di tempat kerja hari ini (Luthans, 2002). Kaitannya dengan profesionalisme, kinerja ditunjukkan melalui kompetensi. Pada penelitian ini yang dimaksudkan dengan profesionalitas dosen ialah atribut dan nilai positif yang diperlihatkan seseorang dalam menjalankan profesinya. Profesionalitas dosen menentukan kualitas pelaksanaan Tridharma Perguruan Tinggi sebagaimana yang ditunjukkan dalam kegiatan profesional dosen. Untuk menjamin pelaksanaan tugas dosen berjalan sesuai dengan kriteria yang ditetapkan dalam peraturan perundang undangan maka perlu dievaluasi setiap periode waktu yang ditentukan. (Dikti, 2010). Penelitian ini bertujuan untuk menggali keterkaitan antara kinerja dan profesionalitas dosen dengan adanya ketentuan jam kerja dosen.

\section{B. LANDASAN TEORI \\ Definisi Kinerja dan Penilaian Kinerja}

Kinerja (performance) adalah hasil pekerjaan yang dicapai seseorang berdasarkan persyaratan-persyaratan pekerjaan (job requirement). Suatu pekerjaan mempunyai persyaratan tertentu untuk dapat dilakukan dalam mencapai tujuan yang disebut juga sebagai standar pekerjaan (job standard) (Bangun, 2012:231).

Secara sederhana pengertian kinerja adalah hasil kerja dan perilaku kerja yang telah dicapai dalam menyelesaikan tugastugas dan tanggung jawab yang diberikan dalam suatu periode tertentu. Dalam praktiknya kinerja dibagi ke dalam dua jenis yaitu kinerja individu dan kinerja organisasi. Kinerja individu merupakan kinerja yang dihasilkan oleh seseorang, sedangkan kinerja organisasi merupakan kinerja perusahaan secara keseluruhan. Namun, kinerja karyawan yang merupakan kinerja individu yang akan mendukung kinerja organisasi.

Gibson mengatakan kinerja individu adalah dasar kinerja organisasi yang sangat dipengaruhi oleh karakteristik individual, motivasi individu, pengharapan,dan penilaian yang dilakukan oleh manajemen terhadap pencapaian hasil kerja individu (Kasmir, 2016:182).

Prestasi kerja (job performance) banyak dibahas oleh para ahli dalam berbagai penelitian. Vroom (1964) juga menjelaskan bahwa prestasi kerja merupakan suatu kombinasi hasil gabungan antara keahlian dan motivasi, dimana keahlian adalah usaha ciri yang stabil (Wijono, 2010:78).

Penimbangan karya merupakan padanan kata dari performance appraisal. Padanan lainnya yang sering digunakan 
ialah 'penilaian prestasi (kerja)', penilaian karya, dan penimbangan unjuk rasa (Munandar, 2001).

\section{Faktor-Faktor Kinerja}

Menurut Suad Husnan (1990:126), faktor-faktor prestasi kerja yang perlu dinilai adalah sebagai beikut:

1. Kuantitas kerja, jumlah pekerjaan yang dapat diselesaikan sesuai dengan waktu yang diharapakan oleh organisasi.

2. Kualitas kerja, mutu hasil pekerjaan yang diperoleh sesuai dengan standar yang diminta oleh pemesan termasukketepatan, ketelitian, keterampilan dan kebersihan hasil kerja.

3. Keandalan, kemampuan memenuhi atau mengikuti instruksi, inisiatif, hati-hati, kerajinan, dan kerja sama.

4. Inisiatif, kemampuan mengenali masalah dan mengambil tindakan korektif, memberikan saran-saran untuk meningkatkan dan menerima tanggung jawab untuk menyelesaikan.

5. Kerajinan, kesediaan melakukan tugas tanpa adanya paksaan dan bersifat rutin.

6. Sikap, perilaku karyawan terhadap perusahaan, atasan, dan teman kerja.

7. Kehadiran, keberadaan karyawan di tempat kerja untuk bekerja sesuai dengan waktu atau jam kerja yang telah ditetapkan.

Penilaian prestasi kerja berdasarkan petunjuk tertentu, sebagaimana penilaian prestasi kerja untuk pegawai negeri sipil yang pelaksanaannya berdasarkan peraturan kepala badan kepegawaian negara nomor satu tahun 2013 dengan landasan hukum (Afifuddin, 2014:172173). Landasan hukum tersebut sebagai berikut:

1. UU No 43 tahun 1999 jo UU No 8 tahun 1974 tentang pokok-pokok kepegawaian.

2. Peraturan Pemerintah No 46 tahun 2011 tentang penilaian prestasi kerja PNS.

3. Peraturan Pemerintah No 53tahun 2010 tentang disiplin PNS

4. Peraturan kepala BKM No 1 tahun 2013 tentang ketentuan pelaksanaan peraturan pemerintah no 46 tahun 2011 tentang penilaian prestasi kerja PNS.

\section{Tujuan Penilaian Kinerja}

Bagi perusahaan penilaian kinerja sangat penting guna memenuhi tujuan yang ingin dicapai baik oleh perusahaan maupun bagi seluruh karyawan. Bagi perusahaan penilaian kinerja memiliki beberapa tujuan antara lain yaitu:

1. Untuk memperbaiki kualitas pekerjaan

2. Keputusan penempatan

3. Perencanaa dan pengembangan karier

4. Kebutuhan pelatihan dan pengembangan

5. Penyesuaian kompensasi

6. Inventori kompetensi pegawai

7. Kesempatan kerja adil

8. Komunikasi efektif antara atasan dan bawahan

9. Budaya kerja

10. Menerapkian sanksi (Kasmir, 2016:196-200).

\section{Komponen Penilaian Kinerja}

Masing-masing komponen memiliki bobot atau nilai tersendiri yang telah ditentukan sesuai dengan beban dan tanggung jawab yang diemban oleh suatu jabatan. Selanjutnya masing-masing komponen yang sudah dinilai dan dijumlahkan sehingga menghasilkan nilai total. Kemudian nilai total dimasukkan ke grade atau tingkatan yang telah ditetapkan.

Untuk memudahkan pemahaman berikut ini masing-masing komponen penilaian kinerja yang umum diberikan yaitu:

1. Absensi

Absensi merupakan keadaan atau bukti kehadiran karyawan pada saat masuk kerja sampai pulang kerja. Misalnya jam masuk kerja adalah jam 08.00 dan pulangnya jam 17.00. Artinya karyawan yang masuk kurang dari atau maksimal pas jam 08.00, maka karyawan tersebut dikatakan 
hadir tepat waktu. Demikian sampai dengan jam 17.00 atau lebih dianggap sudah memenuhi kehadiran selama satu harikerja.

2. Kejujuran

Kejujuran merupakan perilaku karyawan selama bekerjadalam satu periode. Nilai kejujuran seorang karyawan biasanya dinilai berdasarkan ukuran yang telah ditetapkan sebelumnya.

3. Tanggung jawab

Tanggung jawab merupakan unsur yang cukup penting terhadap kinerja seseorang. Artinya karyawan yang memenuhi kriteriabertanggung jawab makanilai kinerjanya akan baik. Demikian pula sebaliknya bagi mereka yang tidak ataukurang bertanggung jawab terhadap pekerjaannya, akandinilai kurang baik.

4. Karyawan

Kemampuan merupakan ukuran bagi seorang karyawan untuk menyelesaikan suatu pekerjaan. Untuk waktu mengerjakan artinya kemampuannya dalam menyelesaikan pekerjaan secara tepat waktu atau lebihcepat dari waktu yang ditentukan.

5. Loyalitas

Loyalitas merupakan kesetiaan seseorang karyawan terhadap perusahaan. seorang karyawan harus selalu setiamembela kepentingan perusahaan. Loyalitas seorang karyawan dapat pula dilihat dari kesetiannya bersama perusahaan dalam kondisi apapun.

6. Kepatuhan

Kepatuhan merupakan ketaatan karyawan dalam mengikuti seluruh kebijakan atau peraturan perusahaan. Atau dengan kata lain kepatuhan adalah ketaatan untuk tidak melanggar atau melawan apa yang sudah diperintahkan. Artinya didalam suatu perusahaan ada yangboleh dilakukan dan ada yang tidak boleh dilakukan.

7. Kerja sama
Kerja sama merupakan saling membantu di antara karyawan baik antara bagian atau dengan bagian lain. Kerja sama ini bertujuan untuk mempercepat atau memperlancar suatu kegiatan. Artinya dengan adanya kerja sama akan mengikis perbedaan dan mengurangi kegagalan dalam suatu kegiatan.

8. Kepemimpinan

Kepemimpinan artinya yang dinilai adalah kemampuan seseorang dalam memimpin. Dalam banyak kasus tidak semua orang memiliki kemampuan untuk memimpin para bawahannya, apalagi dalam kondisi yang beragam.

9. Prakarsa

Prakarsa merupakan seseorang selalu memiliki ide-ide atau pendapat perbaikan atau pengembangan atas kualitas suatu pekerjaan. Prakarsa ini menandadakn seseorang memiliki kepedulian terhadap kemajuan perusahaan.

10. Dan komponen lainnya.

\section{Indikator Penilaian Prestasi Kerja}

Untuk mengukur kinerja karyawan dapat digunakan beberapa indikator mengenai kriteria kinerja yakni: kualitas, kuantitas, ketetapan waktu, efektivitas biaya, kepatuhan akan pengawasan, dan hubungan antar perseorangan. Indikator inilah yang akan menjadi patokan dalam mengukur kinerja karyawan.

Adapun penjelasan dari masingmasing dimensi di atas sebagai berikut:

1. Kualitas (mutu)

Pengukuran kinerja dapat dilakukan dengan melihat kaulitas (mutu) dari pekerjaan yang dihasilkan melalui suatu proses tertentu. Dangan kata lain bahwa kulitas merupakan suatu tingkatan dimana proses atau hasilo dari penyelesaian suatu kegiatan mendekati titik kesempurnaan. Maikn sempurna suatu produk maka kinerja makin baik, demikian pula sebaliknya jika kulaitas pekerjaan yang dihasilkan rendah makan kinerjanya juga rendah. 
2. Kuantitas (jumlah)

Untuk mengukur kinerja dapat dilakukan dengan melihatdari kuantitas (jumlah) dihasilkan seseorang. Dengan kata lain kuantitas merupakan produksi yang dihasilkan dapat ditunjukkan dalam bentuk satuan mata uang, jumlah unit, dan jumlah siklus kegiatan diselesaikan.

3. Waktu (jangka waktu)

Untuk jenis pekerjaan tertentu diberikan batas waktu dalam menyelesaikan pekerjaannya. Artinya ada pekerjaan batas waktu minimal dan maksimal harus dipenuhi (misalnya dalam 30 menit).

4. Penekanan biaya

Biaya yang dikeluarkan untku setiap aktivitas perusahaan sudah dianggarkan sebelum aktivitas dijalankan. Artinya dengan biaya yang sudah dianggarkan tersebut merupakan sebagai acuan agartidak melebihi dari yang sudah dianggarkan.

5. Pengawasan

Dengan melakukan

pengawasankaryawan akan merasa lebih bertanggung jawab atas pekerjaannya dan jika terjadi penyimpangan akan memudahkan untuk melakukan koreksi dan melakukan perbaikan secepatnya. Artinya pengawasan sangat diperlukan dalam rangka mengendalikan aktivitas agar tidak meleset dari yang sudah direncanakan atau ditetapkan.

6. Hubungan antarkaryawan

Hubungan ini seringkali juga dikatakan sebagai hubungan antar perseorangan. Dalam hubungan ini diukur apakah seorang karyawan mampu untuk mengembangkan perasaan saling menghargai, niat baik dan kerja sama antara karyawan yang satu dengan karyawan yang lain (Kasmir: 2016:203-210).

\section{Pengertian Profesionalitas Dosen}

Kamus Besar Bahasa Indonesia membuat artian profesionalitas mempunyai makna; mutu, kualitas, dan tindak tanduk yang merupakan ciri suatu profesi atau yang profesional.

Menurut Veloski, dkk (2005) Profesionalitas dan atribut personal yang berkaitan dengannya, seperti etika, humanisme, dan nilai-nilai personal merupakan salah satu tema yang memainkan peran dalam dunia pendidikan dan industri. Ia menyikapi itu, kompetensi dan etika profesi menjadi kurikulum di dunia pendidikan yang erat kaitannya dengan profesi tertentu, seperti kedokteran, psikologi, hokum, dan akuntansi. Hal ini disebabkan karena profesionalitas memang erat kaitannya dengan profesi.

$$
\text { Sementara Coulehan }
$$

menambahkan bahwa profesionalitas menuntut sikap altruisme, akuntabilitas, ekskelen, tugas, layanan, penghargaan, integritas, dan menghargai orang lain. Definisi ini mencakup layanan, aspirasi, kualitas kerja, dan hubungan. Dalam konteks kerja seperti perlu melibatkan hati proses kerja agar kualitas kinerja menjadi lebih meningkatkan, terutama dalam profesi pelayanan seperti dokter dan dosen.

Oey-Gardiner (2006) bahkan mengatakan dalam konteks penelitian, seorang peneliti dan dosen yang meneliti mesti melakukannya secara profesional. Profesionalitas dalam penelitian ditandai oleh penelitian yang bertujuan menjawab pertanyaan untuk mengetahui keadaan lingkungan realita empiris, baik fisik maupun sosial. (Oey-Gardiner, 2006).

Senada dengan itu, Coulehan (2005) menuliskan bahwa tenaga profesional saat ini hanya melibatkan pikiran dan tidak melibatkan hati dalam profesinya. Seorang profesional dituntut untuk melayani kepentingan kliennya melebihi kepentingan pribadinya. Hal ini memasukkan nilai altruisme, akuntabilitas, excellence, tugas, pelayanan, kebanggaan, integritas, dan menghargai orang lain. Ini mencakup pelayanan, tujuan, dan kualitas. Untuk mencapai hal ini perlu diupayakan model yang memadai, kesadaran diri, kompetensi, dan pelayanan komunitas. 
Keempat hal ini baru akan bermakna jika ia bukan hanya simbol yang diperbincangkan, melainkan seuatu yang mesti dilakukan dari hari ke hari.

Agar kualitas profesi tersebut dapat dijamin, Vleeuten dan Schuwirth (2005) menjelaskan bahwa perlunya evaluasi terhadap pengukuran dan penilaian profesionalitas. Penilaian yang ada saat ini terutama pada profesi pendidikan medis berbasis pada penilaian sendiri, penilaian rekan, dan portofolio. Namun dikarenakan tuntutan kompetensi yang semakin kompleks, maka diperlukan penilaian yang lebih menyeluruh mencakup aspek proses kualitatif dari pelaksanaan profesi. Ini mengimplikasikan adanya upaya untuk mengukur keseluruhan aspek kompetensi dan sumber informasi yang beragam.( dalam Shaleh, 2013).

\section{Pengukuran Profesionalitas}

Uraian di atas menjelaskan pengukuran profesionalitas ditekankan pada kompetensi profesional yang dimiliki oleh seseorang yang menjalani satu profesi. Hutapea dan Thoha (2008) mengutip Miller, Rankin, dan Neathey (2001) merangkum pengertian kompetensi menjadi dalam dua bagian. Pertama, kompetensi tehnik ialah gambaran tentang apa yang harus diketahui atau dilakukan seseorang agar dapat melaksanakan pekerjaannya dengan baik. Kedua, kompetensi perilaku ialah bagaimana seseorang diharapkan berperilaku agar dapat melaksanakan pekerjaannya.

Aspek kompetensi mengacu pada kemampuan dan keterampilan. Wass, et.al. (2001) mengembangkan model pengukuran kompetensi berdasarkan piramida kompetensi Miller. Piramida ini membagi kompetensi menjadi empat aspek, yaitu mengetahui (knows), mengetahui caranya (knows how), menunjukkan (shows how), dan melakukan (does). Aspek mengetahui merupakan sekumpulan pengetahuan yang diperlukan dalam sesuai dengan tuntutan pekerjaan. Dalam konteks akademik, aspek mengetahui merupakan penguasaan terhadap bidang ilmu yang dimilikinya. Aspek mengetahui caranya terkait dengan pengetahuan teknis bagaimana ia akan melaksanakan pekerjaannya.

Navarro, Mas, dan Jimenez (2010) berupaya melakukan uji terhadap pengukuran kompetensi di tempat kerja pada profesor di Universitas dan mengelompokkan kompetensi menjadi tiga dimensi, yaitu kompeten, over-kualifikasi, dan kehilangan sumber daya. Overkualifikasi merujuk pada penilaian seseorang bahwa ia melebihi kapasitas yang diperlukan berdasarkan persyaratan pekerjaannya. Kompeten menunjukkan bahwa ia mampu dan sesuai dalam melakukan tuntutan pekerjaan. Sedangkan kehilangan sumber daya memperlihatkan penilaian bahwa ia tidak kompeten dalam bidang pekerjaannya. Tiga komponen ini merupakan pengukuran terhadap istilah yang dikenal dengan merasa kompeten (perceived competence). Perceived competence ini diukur melalui 20 item yang terdiri dari 10 item mengukur aspek kompetensi, 7 item mengukur overkualifikasi, dan 3 item mengukur kehilangan sumber daya.

Berbeda dengan itu, Tromp, dkk. (2007) menyebutkan bahwa nilai-nilai profesionalitas yang menjadi ukuran bagi kompetensi mestilah diarahkan pada pembentukan perilaku. Oleh karena itu, Tromp dkk. (2007) menggunakan empat nilai, yaitu tanggung jawab, kejujuran dan kematangan, keterampilan interpersonal, dan sikap menghargai.

\section{METODE}

Pendekatan yang digunakan dalam penelitian ini adalah pendekatan penelitian kuantitatif, yang menekankan analisisnya pada data-data numerikal (angka), yang diolah dengan metode statistika (Azwar, 2010:5). Sampel dalam penelitian ini adalah dosen di UIN Imam Bonjol Padang sebanyak 173 sampel.

\section{HASIL DAN PEMBAHASAN}




\section{Kinerja}

Untuk melihat bagaimana kinerja dosen diukur dengan menggunakan skala. Skala yang digunakan untuk mengukur variabel tersebut terdiri 41 aitem dengan nilai Cronbach alpha sebesar 0.95 . Nilai daya beda terendah untuk aitem dalam skala penerapan jam kerja adalah 0.33 dan daya beda tertinggi adalah sebesar 0.73 . Artinya dari nilai reliabilitas dan daya beda aitem sudah memuaskan.

\section{Profesionalisme}

Banyaknya aitem yang digunakan untuk mengukur profesionalisme dosen adalah 15 aitem. Nilai daya beda terendah dari aitem profesionalisme adalah sebesar 0.26 dan yang tertinggi adalah 0.70 . Nilai Cronbach alpha untuk skala profesionalisme adalah sebesar 0.86. Dari hasil-hasil tersebut dapat dikatakan skala profesionalisme dosen sudah memuaskan.

\section{Statistik deskriptif}

Statistik deskriptif dilakukan guna untuk melihat gambaran secara umum pemusatan dan penyebaran data pada dua variabel. Hasil analisis yang dilakukan didapatkan seperti berikut.

Tabel 1 Statistik Deskriptif

\begin{tabular}{lll}
\hline & Kinerja & Profesionalisme \\
\hline $\mathrm{N}$ & 173 & 173 \\
Max & 204 & 75 \\
Min & 101 & 39 \\
Mean & 159,18 & 62,38 \\
Varian & 397,37 & 53,79 \\
SD & 19,93 & 7,33 \\
\hline
\end{tabular}

Dari tabel 1 terlihat bahwa banyaknya dosen yang berpartisipasi adalah sebanyak 173 orang. Skor kinerja dosen memiliki nilai terendah 101 dan nilai tertinggi 204 dengan rerata sebesar 159.18. Varian untuk kinerja dosen adalah sebesar 397.37 dan standar deviasi sebesar 19.93.

Sedangkan untuk variabel profesionalisme, nilai tertinggi dari dosen adalah sebesar 75 dan nilai terendah sebesar 39 dengan nilai mean 60.80. Nilai varian dan standar deviasi untuk variabel ini adalah berturut-turut 60.03 dan 7.75.

\section{Kategorisasi profesionalisme dan kinerja}

variabel

Peneliti juga melihat kategori dari variabel profesionalisme dan kinerja. Kategori dikategorikan menjadi dua tinggi dan rendah. Hasil dari kategori seperti pada tabel 2.

Tabel 2. Hasil Kategorisasi

\begin{tabular}{llll}
\hline Variabel & Kategori & Jumlah & Persen \\
\hline Kinerja & Tinggi & 88 & $50.87 \%$ \\
& Rendah & 85 & $49.13 \%$ \\
Profesion & Tinggi & 94 & $54.34 \%$ \\
alisme & Rendah & 79 & $45.66 \%$ \\
\hline
\end{tabular}

Dari tabel 2 terlihat bahwa sebagian besar dosen memiliki kinerja pada kategori tinggi yaitu sebanyak 88 orang atau $49.13 \%$. Sedangkan dosen yang memiliki kinerja yang rendah sebanyak 85 orang atau $49.13 \%$.

Pada variabel profesionalisme sebagian besar juga menunjukkan dosen memiliki kategori tinggi yaitu sebanyak 94 orang atau $54.34 \%$. Dosen yang memiliki kategori rendah adalah sebanyak 79 orang atau $45.66 \%$.

\section{Uji Regresi}

Uji regresi digunakan untuk melihat berapa besar profesionalisme dan banyaknya jam mengajar dosen berpengaruh terhadap kinerrja mereka. Nilai sumbangan variabel profesionalisme dan jumlah jan kerja dosen terhadap kinerja mereka dapat dilihat dari nilai $\mathrm{R}$ square yang diubah menjadi bentuk persen. Hasil dari analisis regresi adalah sebagai berikut.

Tabel 3. Model Summary

\begin{tabular}{ll}
\hline $\mathrm{R}$ & .59 \\
\hline Rsquare & 0.34 \\
\hline
\end{tabular}


Adjusted Rsquare $\quad 0.31$

Std. Error $\quad 6.10$

Dari tabel 3 terlihat besarnya korelasi antara profesionalisme dan banyaknya jam kerja dosen berkorelasi positif dengan kinerja dengan nilai $r$ sebesar 0.56 . Artinya semakin tinggi profesionalisme dan jam kerja dosen maka akan semakin tinggi pula kinerja mereka. Dari tabel 4.3 juga terlihat sumbangan efektif variabel penerapan jam kerja dosen terhadap profesionalisme yaitu sebesar 31\%. Artinya, sebesar 31\% profesionalisme dan jam kerja dosen berpengaruh terhadap kinerja mereka.

Tabel 4 ANOVA

\begin{tabular}{llll}
\hline & Regression & Residual & Total \\
\hline $\begin{array}{l}\text { Sum of } \\
\text { square }\end{array}$ & 2884.07 & 6368.50 & 9252.58 \\
F & & 71 & 72 \\
$\begin{array}{l}\text { Mean } \\
\text { of } \\
\text { square }\end{array}$ & 2884.07 & 38.24 & \\
F & 77.44 & & \\
Sig. & 0.001 & & \\
\hline
\end{tabular}

Tabel 4 menampilkan hasil dari model yang dibuat, artinya apakah kinerja dan jumlah jam kerja oleh dosen berpengaruh dengan signifikan terhadap profesionalisme mereka atau tidak. Dari hasil di atas didapatkan nilai $\mathrm{F}$ sebesar 77.44 dengan nilai $\mathrm{p}$ sebesar 0.001 ( $\mathrm{p}<$ 0.05 ) yang berarti model yang dibuat adalah signifikan. Dengan arti kata bahwa kinerja dan jumlah jam kerja dosen berpengaruh terhadap profesionalitas dosen.

\section{PEMBAHASAN}

Kinerja merupakan nilai dari perilaku yang diharapkan dapat memberikan kontribusi bagi kinerja organisasi secara keseluruhan dan tertuang dalam standar dan uraian kerja. Pengertian ini menjadikan kinerja lebih dekat dengan perilaku dan bukan pada hasil dari perilaku itu sendiri. Namun demikian kinerja dan perilaku merupakan hal yang berbeda. Senada dengan itu, Jansel dan Van Yperen
(2004) berpendapat bahwa kinerja dapat didefinisikan sebagai tindakan yang dikhususkan dan diperlukan oleh uraian kerja dan yang diminta, diukur, serta diawasi kembali. Bakker, Emmerik, dan van Riet (2008) menyebutkan bahwa kinerja merujuk pada perilaku pekerja yang diduga memberi kontribusi pada efektivitas organisasi dan kinerja organisasi keseluruhan.

Dalam konteks dosen, kinerja dosen berarti memenuhi tugas dan fungsi dosen dalam melaksanakan fungsi tridharma perguruan tinggi. Dosen adalah seseorang yang berdasarkan pendidikan dan keahliannya diangkat oleh penyelenggaraan pendidikan tinggi dengan tugas utama mengajar pada perguruan tinggi yang bersangkutan. Berdasarkan UU No.14 tahun 2005 tentang Guru dan Dosen, Dosen adalah pendidik profesional dan ilmuwan dengan tugas utama mentransformasikan, mengembangkan, dan menyebarluaskan ilmu pengetahuan, teknologi dan seni melalui pendidikan, penelitian dan pengabdian kepada masyarakat. Kinerja dosen dinilai melalui evaluasi aktifitas atau kegiatan (proses) yang dilakukan oleh dosen yang berhubungan dengan pelaksanaan tugas pokoknya sebagai dosen, yang meliputi aspek-aspek perencanaan, pelaksanaan dan evaluasi pendidikan.

Dosen bertugas menyelenggarakan kegiatan mengajar, melatih, meneliti, mengembangkan, mengelola dan memberikan pelayanan teknis dalam bidang pendidikan. Dalam konteks yang lebih operasional, tugas dan tanggung jawab dosen dalam melaksanakan Tri Dharma Perguruan Tinggi yaitu: (1) Tugas dan tanggung jawab dalam pendidikan dan pengajaran meliputi: (a) mengelola program perkuliahan (b) mengelola laboratorium (c) membimbing praktek laboratorium (d) memberi layanan pelajaran remedial. (2) Tugas dan tanggung jawab dalam bidang penelitian meliputi: (a) mengadakan penelitian 
ilmiah (b) membimbing mahasiswa dalam menyusun karya tulis atau skripsi (c) berpartisipasi dalam kegiatan seminar dan berbagai kegiatan ilmiah lainnya. (3) Tugas dan tanggung jawab dalam bidang pengabdian masyarakat meliputi: (a) membimbing mahasiswa dalam praktek kerja di masyarakat (b) mengaplikasikan ilmunya untuk peningkatan kesejahteraan masyarakat (c) merencanakan, melaksanakan dan pembentukan serta pembinaan kader pembangunan untuk meningkatkan kesejahteraan rakyat. (Dikti, 2010). Tugas penelitian mencakup merancang dan melaksanakan penelitian serta mempubilkasikannya dalam bentuk jurnal dan buku. Adapun tugas pengabdian masyarakat terkait dengan keterlibatan dan peran serta dalam pengembangan masyarakat dan kepanitian. Keseluruhan tugas-tugas dosen tersebut dinilai melalui uraian dalam beban kerja dosen. Program Beban Kerja Dosen dan Evaluasi Pelaksanaan Tridharma Perguruan Tinggi (BKD dan EPT-PT) dikeluarkan oleh Dirjen Pendidikan Tinggi untuk menjamin pelaksanaan tugas dosen berjalan sesuai dengan kriteria yang telah ditetapkan dalam peraturan perundang-undangan.

\section{E. SIMPULAN}

Tugas utama dosen adalah melaksanakan tridharma perguruan tinggi. Temuan penelitian ini adalah bahwa kinerja mempengaruhi profesionalitas dosen. Penerapan jam kerja yang optimal akan menimbulkan kinerja dan kinerja yang baik akan tercipta profesionalitas dosen.

\section{DAFTAR KEPUSTAKAAN}

Azwar, S. (2003). Penyusunan Skala Psikologi. Yogyakarta: Pustaka Pelajar.

Armstrong. (2009). Teacher pay in south africa: how attractive is the teaching profession? Stellenbosch Economic Working Papers: 04/09

Bakker, A.B. and Schaufeli, W.B. (2008). Positive organizational behavior: Engaged employees in flourishing organizations. J. Organiz. Behav, 29, 147-154. DOI: 10.1002/job.515

Cameron, K.S. (2005). Organizational Effectiveness: Its Demise and Reemergence through Positive Organizational Scholarship. dalam Michael A. Hitt and Ken G. Smith (Eds.) Handbook of Management Theory: The Process of Theory Development. London: Oxford University Press.

Dirjen Dikti, (2010a). Buku Pedoman Sertifikasi Pendidik Untuk Dosen 2010. Buku 1. Jakarta, Dirjen Dikti

Dirjen Dikti. (2010b). Pedoman beban kerja dosen dan evaluasi pelaksanaan tridharma perguruan tinggi. Jakarta : Dirjen Dikti

Hemmings, B. dan Kay. R. (2009). Lecturer self efficacy: Its related dimensions and the influence of gender and qualifications Issues in Educational Research, 19(3), 243.

Hutapea, P. dan Thoha, M. (2008). Kompetensi plus : Teor, disain, kasus, penerapan, untuk HR dan organisasi dinamis. Jakarta : Gramedia Pustaka Utama

Kasmir. 2016. Manajemen Sumber Daya Manusia. Jakarta: Rajawali Pers.

Motowidlo, S.J.. (2003). Job performance. dalam Borman, W.C., Ilgen, D.R., Klimoski, Richard J.. (Ed.) Handbook of Psychology Volume 12 Industrial And Organizational Psychology. New York: Sage Publications. 
Munandar, Ashar Sunyoto. 2001. Psikologi Industri dan Organisasi. Jakarta: Universitas Indonesia (UI-Press).

Nurzaman, Kadar. 2014. Manajemen Personalia. Bandung: Pustaka Setia.

Periantalo, J. (2015). Penyusunan Skala Psikologi: Asyik, Mudah dan Bermanfaat. Yogyakarta: Pustaka Pelajar.

Wijono, Sutarto. 2010. Psikologi Industri dan Organisasi. Jakarta: Kencana.

Wilson, Bangun. 2012. Manajemen SumberDaya Manusia. Jakarta: Erlangga.

Navarro, M.L.A., Mas, M.B. dan Jiménez, A.M.L. (2010). Working conditions, burnout and stress symptoms in university professors: Validating a structural model of the mediating effect of perceived personal competence. The Spanish Journal of Psychology. 13(1), 284-296

Pusat Bahasa, (2005) KBBI. Jakarta : Pusat Bahasa

Rethans, dkk. (2002). The relationship between competence and performance: implications for assessing practice performance. $\underline{\text { Med }}$ Educ. 36(10), 901-9.

Shaleh, Abdul Rahman (2013). Faktorfaktor personal yang mempengaruhi kinerja dosen. 2013. (disertasi) tidak diterbitkan.

Schmitt, N. dkk. (2003). Personnel selection and employee performance. dalam Borman, W.C., Ilgen, D.R., Klimoski, Richard J.. (Ed.) Handbook of Psychology Volume 12 Industrial And Organizational
Psychology. New York : Sage Publications.

Seniati, L. (2006). Pengaruh masa kerja, trait kepribadian, kepuasan kerja, dan iklim psikologis terhadap komitmen dosen pada universitas indonesia. Makara, Sosial Humaniora, 10(2), 88-97

Suartika, I.M., Suwignjo, P., dan Syairuddin, B. (2007). Perancangan dan implementasi system pengukuran kinerja dengan metode integrated performance measurement systems (Studi kasus : Jurusan teknik mesin universitas mataram). Jurnal Teknik Industri . 9(2), 131-143

Swanson, R. A. (1999). The foundations of performance improvement and implications for practice. In R. Torraco (Ed.), The theory and practice of performance improvement. Berrett-Koehler: San Francisco.

Tromp, et.al. (2007) Development for an instrument to assess profesional of foreign medical graduates. Medical Teacher, 29(23), 50-55

Wijono Sutarto. 2010. Psikologi Industri dan Organisasi. Jakarta: Kencana.

Wilson, Bangun. 2012. Manajemen Sumber Daya Manusia. Jakarta: Erlangga.

Surat Edaran Rektor UIN Imam Bonjol Padang Tentang Jam Kerja Dosen. 